$\underline{\underline{\beta}}=-1$

\title{
Ethanolic leaf extract of Irvingia gabonensis (o'Rorke) Baill protects against nephrotoxocity and hepatotoxicity in cadmium-induced wistar albino rats
}

\author{
Efosa Godwin Ewere ${ }^{1 *}$, Samson Adewale Oyebadejo ${ }^{2}$, Victor Chukwuebuka Peter ${ }^{1}$ \\ ${ }^{1}$ Biochemistry Department, Faculty of Basic Medical Sciences, University of Uyo P.M.B. 1017, Uyo, Akwa Ibom State, Nigeria; \\ ${ }^{2}$ Anatomy Department, Faculty of Basic Medical Sciences, University of Uyo, Akwa Ibom State, Nigeria \\ *Corresponding author E-mail:efosaewere@yahoo.com
}

\begin{abstract}
Cadmium is a well-known environmental pollutant that has been proven to be nephrotoxic and hepatotoxic in the body. In this study, the effect of ethanolic leaf extract of Irvingia gabonensis (O'Rorke) Baill (IG) against cadmium-induced nephrotoxicity and hepatotoxicity in Wistar albino rats was investigated. 30 female wistar rats of weights between 98-153g were grouped into 6 groups of 5 animals each. Group 1 served as the control and was placed on rat feed and water. Groups 2, 3, and 4 were administered $10 \mathrm{mg} / \mathrm{Kg}$ body weight (mg/kgbw) of cadmium chloride $\left(\mathrm{CdCl}_{2}\right)$ only, $10 \mathrm{mg} / \mathrm{Kgbw} \mathrm{CdCl}_{2}$ and $200 \mathrm{mg} / \mathrm{kgbw}$ extract, $10 \mathrm{mg} / \mathrm{Kgbw} \mathrm{CdCl} \mathrm{L}_{2}$ and $400 \mathrm{mg} / \mathrm{kgbw}$ extract, respectively. Groups 5 and 6 were given $200 \mathrm{mg} / \mathrm{kgbw}$ and $400 \mathrm{mg} / \mathrm{kgbw}$ of IG extract respectively and the treatments lasted for 28 days. Results obtained revealed significant $(\mathrm{p}<0.05)$ increases in the serum levels of all renal and liver function biomarkers in group $2\left(\mathrm{CdCl}_{2}\right.$ only) as compared with the control. There were however significant $(\mathrm{p}<0.05)$ decreases in the serum levels of the assayed parameters when groups 3 and 4 were respectively compared with group 2. It can therefore be concluded that ethanolic leaf extract of Irvingia gabonensis (O'Rorke) Baill enhances the integrity of the kidneys and liver of cadmium-induced wistar albino rats.
\end{abstract}

Keywords: Irvingia Gabonensis (O'Rorke) Baill; Cadmium; Nephrotoxicity; Hepatotoxicity; Biomarkers.

\section{Introduction}

Cadmium is a heavy metal belonging to group IIB of the periodic table of elements. It is a relatively rare element that occurs naturally in ores together with zinc, lead and copper or is emitted into the air through volcanic emission (Jarup et al. 1998, 2000) and poses severe risks to human health till date, without any physiological function within the human body (Johannes et al. 2006). Cadmium has several applications especially in industrial processes, its harmful effects notwithstanding. For instance, it can serve as an anticorrosive agent, a stabilizer in PVC products, a colour pigment, a neutron-absorber in nuclear power plants, and used in the fabrication of nickel-cadmium batteries as well as in production of phosphate fertilizers (Johannes et al. 2006). Cadmium has been on the increase in the environment due to anthropogenic factors like waste incineration and fossil fuel combustion (Ambily et al. 2013). Unlike other heavy metals, it has increased concentration in agricultural soils and this is attributed to application of phosphate fertilizers, sewage sludge, waste water, and pesticides (Limei et al. 2008). Other sources of cadmium include; mining at mines, smelting of ores, and its application in making nickel-cadmium batteries (Liao et al. 2005). Humans are at a high risk for cadmium as it accumulates in the body tissues and organs such as the liver, lungs, kidneys, bones, and reproductive organs (Thijssen et al. 2007, Alvarez et al. 2007) leading to dysfunction and oxidative damage in the various tissues as a result of induced oxidative stress through release of reactive oxygen species (ROS) (Liu et al. 2008).
The liver and kidneys are the most susceptible organs to cadmium toxicity (Asagba et al. 2004, Abd-El-Baset et al. 2008). Cadmium has a high tendency to settle in the proximal tubule of the nephron, leading to nephrotoxicity and progressive renal failure (Gonick, 2008) and this nephrotoxicity caused by cadmium is markedly high in occurrence among individuals exposed to the heavy metal industrially and/or through food as well as environmental pollution (Gonick, 2008). Several studies have reported hepatotoxicity associated with cadmium intoxication in (Amin et al. 2006, Alhazzi, 2008, Tarasub et al. 2008 Rajasekaran and Periasamy, 2012). Other biochemical effects of cadmium include displacement of redox-active metals, depletion of redox scavengers, inhibition of anti-oxidant enzymes, and inhibition of the electron transport chain resulting in mitochondrial damage (Thevenod 2009, Cuypers et al. 2010).

Over the years, medicinal plants have been applied by herbal medicine practitioners and most locals for preventive, therapeutic and curative purposes. One of such plants is Irvingia gabonensis (O'Rorke) Baill. Classified as a non-timber forest tree, Irvingia gabonensis (O'Rorke) Baill is commonly called bush mange or African mango as the trees bear small mango-like fruits (Matos et al. 2009). It is a tropical forest tree commonly found in Southern and Eastern Nigeria, Sierra Leone and Equatorial Africa and it is a species from the family Irvingiaceae. It has a sweet and edible fruit pulp with a characteristic turpentine flavour (Udeala et al. 1980). Traditionally, the leaves are widely used for the treatment of several illnesses (Lowe et al. 2000). The aqueous maceration of the leaves is used as antidote for some poisonous substances. The leaves are used to stop haemorrhage in pregnant women when combined with palm oil. The decoction of the stem bark is used in 
the treatment of gonorrhoea, hepatic and gastrointestinal disorders in Senegal (Hubert et al. 2010). The leaf extracts of the plant has been reported to have diuretic effect in rats and hypotensive effect in cats (Nosiri et al. 2009a; 2009b). The stem bark of the tree is added to palm wine as a preservative (NAERLS, 1999).

There is however a dearth of information on the renal protective and hepatoprotective effects of ethanolic leaf extracts of Irvingia gabonensis (O'rorke) baill on cadmium-induced toxicity in wistar albino rats. This is what informed this study.

\section{Materials and methods}

\subsection{Reagents and chemicals}

Cadmium chloride was purchased from Kermel chemical co. ltd, China. Urea, creatinine, sodium $\left(\mathrm{Na}^{+}\right)$, bicarbonate $\left(\mathrm{HCO}_{3}^{-}\right)$, potassium $\left(\mathrm{K}^{+}\right)$,total protein as well as aspartate aminotransferase (AST), alanine aminotransferase (ALT), alkaline phosphatase (ALP) and gamma glutamyl transferase (GGT) assay kits were purchased from Teco Diagnostics, USA. All other reagents and chemicals used were of analytical grades

\subsection{Collection and preparation of test plant samples}

Fresh and matured leaves of Irvingia gabonensis (O'Rorke) Baill were obtained from Obong Itam village in Itu local government area of Akwa Ibom State, Nigeria and authenticated by a plant taxonomist of the Department of Botany, University of Uyo, with the herbarium number: SAM, UUH 3396 (Itu). The leaves were washed, rinsed with deionized water and air-dried for one week The dried leaves were pulverized and macerated in $80 \%$ ethanol for 72 hours. It was then filtered and concentrated with a water bath at $45^{\circ} \mathrm{C}$ into a paste and used for the experiment.

\subsection{Experimental design}

Thirty (30) healthy female wistar albino rats of weights between 98-153g were allowed to acclimatize for 14 days in standard rat cages under standard laboratory conditions having free access to commercial rat feed (vital grower) and water. They were then randomized into six (6) groups of five (5) animals each as follows:

Table 1: Protocol for treatment of experimental animals

\begin{tabular}{|c|c|}
\hline Treatment groups & Treatment \\
\hline Group 1 (Control) & Normal Feed + Water \\
\hline Group 2 & $10 \mathrm{mg} / \mathrm{kgbw} \mathrm{CdCl}_{2}$ only \\
\hline Group 3 & $\begin{array}{l}10 \mathrm{mg} / \mathrm{kgbw} \mathrm{CdCl}_{2}+200 \mathrm{mg} / \mathrm{kgbw} \\
\text { ELEIG }\end{array}$ \\
\hline Group 4 & $\begin{array}{l}10 \mathrm{mg} / \mathrm{kgbw} \mathrm{CdCl}_{2}+400 \mathrm{mg} / \mathrm{kgbw} \\
\text { ELEIG }\end{array}$ \\
\hline Group 5 & $200 \mathrm{mg} / \mathrm{kgbw}$ ELEIG \\
\hline Group 6 & $400 \mathrm{mg} / \mathrm{kgbw}$ ELEIG \\
\hline \multicolumn{2}{|c|}{$\begin{array}{l}\text { ELEIG = Ethanolic Leaf Extract of Irvingia gabonensis (O'Rorke) Baill. } \\
\mathrm{mg} / \mathrm{kgbw}=\text { milligram per kilogram body weight }\end{array}$} \\
\hline \multicolumn{2}{|c|}{$\begin{array}{l}\text { Experimental animal treatments were by oral intubation and done } \\
\text { daily for a period of twenty eight (28) days. The doses of the leaf } \\
\text { extract administered were chosen knowing that the } \mathrm{LD}_{50} \text { of the } \\
\text { ethanolic leaf extract of Irvingia gabonensis (O'Rorke) Baill is } \\
\text { above } 5000 \mathrm{mg} / \mathrm{kg} \text { body weight (Ewere et al. 2016). }\end{array}$} \\
\hline
\end{tabular}

Experimental animals were sacrificed 24 hours after the las treatment, having been placed on a 12 hour overnight fast, and weighed to obtain the final body weights. Sacrifice was done un- der ketamine hydrochloride anesthesia by lower abdominal incision and blood was collected by cardiac puncture into plain blood collection tubes. The blood samples were spun in the centrifuge (80-2 centrifuge) at $3000 \mathrm{rpm}$ for $20 \mathrm{mins}$ and the sera obtained were used for the biochemical analyses.

\subsection{Biochemical analyses}

Renal function parameters such as \{urea, creatinine, sodium $\left(\mathrm{Na}^{+}\right)$, bicarbonate $\left(\mathrm{HCO}_{3}^{-}\right)$, potassium $\left(\mathrm{K}^{+}\right)$and total protein $\}$and liver function biomarkers \{aspartate aminotransferase (AST), alanine aminotransferase (ALT), alkaline phosphatase (ALP) and gamma glutamy transferase (GGT) \} were assayed using Teco Diagnostics assay kits according to manufacturer's protocol. Serum potassium estimation was done according to the method of Tietz, 1976. Serum sodium estimation was carried out as described by Maruna, 1958 and Trinder, 1951. Serum bicarbonate was estimated according to the method described by Young, 1990. Serum creatinine was estimated according to the method described by Heinegard and Tiderstrom 1973. The serum urea concentration was estimated by Blood Urea Nitrogen (BUN) reagent (colorimetric method); a modification of Berthelot reaction (Tobacco et al. 1979).

The serum AST activity was determined by kinetic method (Young, 1990). Serum ALT activity was determined by colorimetric endpoint method (Young et al. 1975). Serum ALP activity was determined by colorimetric endpoint method (Kochmar and Moss, 1974) and the activity of GGT was determined by kinetic method (Young, et al. 1975).

\subsection{Statistical analysis}

Results obtained were expressed as mean \pm Standard deviation. DATA between the groups were analyzed by one-way analysis of variance (ANOVA) using Statistical Package for Social Sciences (SPSS). $\mathrm{P}$ values less than $0.05(\mathrm{P}<0.05)$ were considered statistically significant.

\section{Results}

\subsection{Effect of ethanolic leaf extract of Irvingia gabonen- sis (O'rorke) baill) on kidney function of cadmium- induced wistar albino rats}

The effect of Irvingia gabonensis (O'rorke) baill leaf extract on kidneys was assessed by evaluating the levels of some renal function biomarkers: urea, creatinine, electrolytes (sodium, potassium and bicarbonate) and total protein in the treatment groups. There was about two-fold significant $(\mathrm{p}<0.05)$ increase in the serum level of urea $(33.40 \pm 5.81 ; 15.60 \pm 2.70)$, more than double the level of creatinine $(0.90 \pm 0.51 ; 0.32 \pm 0.13)$ and significant $(\mathrm{p}<0.05)$ increases in total protein and electrolytes level in the cadmium exclusively treated group (group 2) when compared with the control. A dose-dependent significant $(p<0.05)$ reductions were observed in the serum levels of urea, sodium, and bicarbonate, when the ameliorative treatment groups (groups 3 and 4) were compared with the cadmium exclusively treated group (group 2). Although not significant, there was however a decrease in the serum level of potassium when the ameliorative treatment groups (groups 3 and 4) were compared with the cadmium exclusively treated group (group 2). Treatment with the extract also significantly $(\mathrm{p}<0.05)$ reduced the serum total protein concentration when the ameliorative treatment groups (groups 3 and 4) were compared with the cadmium exclusively treated group (group 2 ). Treatment with the extract alone (groups 5 and 6) showed nonsignificant $(p>0.05)$ differences in all assayed parameters compared with the control with the exception of the total protein concentrations. 
Table 2: Effect of ethanolic leaf extract of Irvingia gabonensis (O'rorke) baill on kidney function biomarkers of cadmium-induced wistar albino rats

\begin{tabular}{|c|c|c|c|c|c|c|}
\hline $\begin{array}{l}\text { Treatment } \\
\text { groups }\end{array}$ & $\begin{array}{l}\text { Urea } \\
(\mathrm{mg} / \mathrm{dl}\end{array}$ & $\begin{array}{l}\text { Creati- } \\
\text { nine } \\
(\mathrm{mg} / \mathrm{dl})\end{array}$ & $\begin{array}{l}\mathrm{Na}^{+} \\
(\mathrm{mmol} \\
\text { /l) }\end{array}$ & $\begin{array}{l}\mathrm{K}^{+} \\
(\mathrm{mmo} \\
1 / 1\end{array}$ & $\begin{array}{l}\mathrm{HCO}_{3}^{-} \\
(\mathrm{mmol} \\
\text { /1) }\end{array}$ & $\begin{array}{l}\text { Total } \\
\text { pro- } \\
\text { tein } \\
(\mathrm{g} / \mathrm{dl} \\
)\end{array}$ \\
\hline 1.Control & $\begin{array}{l}15.60 \\
\pm \\
2.70^{b}\end{array}$ & $\begin{array}{l}0.32 \pm \\
0.13^{\mathrm{b}}\end{array}$ & $\begin{array}{l}146.8 \\
0 \pm \\
2.59^{b}\end{array}$ & $\begin{array}{l}5.06 \\
\pm \\
2.16^{\mathrm{b}}\end{array}$ & 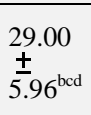 & $\begin{array}{l}5.60 \\
\pm \\
0.52^{\mathrm{b}} \\
\text { ef }\end{array}$ \\
\hline $\begin{array}{l}2.10 \mathrm{mg} / \mathrm{kgbw} \\
\mathrm{CdCl}_{2}\end{array}$ & $\begin{array}{l}33.40 \\
\pm \\
5.81^{\text {acd }}\end{array}$ & $\begin{array}{l}0.90 \pm \\
0.51^{\text {acd }}\end{array}$ & $\begin{array}{l}166.4 \\
0 \pm \\
11.99^{\mathrm{a}}\end{array}$ & $\begin{array}{l}7.18 \\
\pm \\
1.94^{\mathrm{a}}\end{array}$ & $\begin{array}{l}42.00 \\
\pm \\
\frac{ \pm}{4.36^{\mathrm{ad}}}\end{array}$ & $\begin{array}{l}8.38 \\
\pm \\
0.60^{\mathrm{a}} \\
\mathrm{cd}\end{array}$ \\
\hline $\begin{array}{l}3.10 \mathrm{mg} / \mathrm{kgbw} \\
\mathrm{CdCl}_{2}+200 \mathrm{mg} / \\
\text { kgbw ELEIG }\end{array}$ & $\begin{array}{l}20.2 \\
\pm \\
\mathbf{3 . 9 6}\end{array}$ & $\begin{array}{l}0.42 \pm \\
0.13^{\mathrm{b}}\end{array}$ & $\begin{array}{l}150.0 \\
0 \pm \\
1.22^{\mathrm{b}}\end{array}$ & $\begin{array}{l}5.70 \\
\pm \\
1.74\end{array}$ & $\begin{array}{l}36.20 \\
\pm \\
2.86^{\mathrm{a}}\end{array}$ & $\begin{array}{l}5.84 \\
\pm \\
0.70^{b}\end{array}$ \\
\hline $\begin{array}{l}4.10 \mathrm{mg} / \mathrm{kgw} \\
\mathrm{CdCl}_{2}+ \\
400 \mathrm{mg} / \mathrm{kgbw} \\
\text { ELEIG }\end{array}$ & $\begin{array}{l}19.20 \\
\pm \\
2.39^{\mathrm{b}}\end{array}$ & $\begin{array}{l}0.42 \pm \\
0.13^{\mathrm{b}}\end{array}$ & $\begin{array}{l}145.0 \\
0 \pm \\
3.39^{b}\end{array}$ & $\begin{array}{l}6.08 \\
\pm \\
0.69\end{array}$ & $\begin{array}{l}35.60 \\
\pm \\
\frac{ \pm}{3.21^{\mathrm{ab}}}\end{array}$ & $\begin{array}{l}6.18 \\
\pm \\
0.51^{\mathrm{b}}\end{array}$ \\
\hline $\begin{array}{l}5.200 \mathrm{mg} / \mathrm{kgbw} \\
\text { ELEIG }\end{array}$ & $\begin{array}{l}19.40 \\
\pm \\
\frac{ \pm}{6.07^{f}}\end{array}$ & $\begin{array}{l}0.34 \pm \\
0.17\end{array}$ & $\begin{array}{l}144.8 \\
0 \pm \\
3.27\end{array}$ & $\begin{array}{l}5.34 \\
\pm \\
0.45\end{array}$ & $\begin{array}{l}31.60 \\
\pm \\
\frac{ \pm}{6.88^{f}}\end{array}$ & $\begin{array}{l}7.06 \\
\pm \\
0.11^{\mathrm{a}}\end{array}$ \\
\hline $\begin{array}{l}6.400 \mathrm{mg} / \mathrm{kgbw} \\
\text { ELEIG }\end{array}$ & $\begin{array}{l}14.00 \\
\pm \\
1.58^{\mathrm{e}} \\
\end{array}$ & $\begin{array}{l}0.29 \pm \\
0.09\end{array}$ & $\begin{array}{l}143.0 \\
0 \pm \\
2.00 \\
\end{array}$ & $\begin{array}{l}4.48 \\
\pm \\
0.33 \\
\end{array}$ & $\begin{array}{l}24.60 \\
\pm \\
1.14^{\mathrm{e}}\end{array}$ & $\begin{array}{l}6.94 \\
\pm \\
0.11^{\mathrm{a}}\end{array}$ \\
\hline
\end{tabular}

Data expressed as Mean \pm SD

$\mathrm{ELEIG}=$ ethanolic leaf extract of Irvingia gabonensis (O'rorke) baill

$\mathrm{a}=$ mean difference statistically significant at $\mathrm{P}<0.05$ when compared with group 1 (control)

$\mathrm{b}=$ mean difference statistically significant at $\mathrm{P}<0.05$ when compared with group 2

$\mathrm{c}=$ mean difference statistically significant at $\mathrm{P}<0.05$ when compared with group 3

$\mathrm{d}=$ mean difference statistically significant at $\mathrm{P}<0.05$ when compared with group 4

$\mathrm{e}=$ mean difference statistically significant at $\mathrm{P}<0.05$ when compared with group 5

$\mathrm{f}=$ mean difference statistically significant at $\mathrm{P}<0.05$ when compared with group 6

\subsection{Effect of ethanolic leaf extract of Irvingia gabonen- sis (o'rorke) baill on liver function of cadmium-induced wistar albino rats.}

The effect of Irvingia gabonensis (O'Rorke) Baill) leaf extract on liver function was assessed by evaluating the activities of serum enzymes; AST, ALT, ALP and GGT in all the treated groups. Administration of cadmium resulted in more than a threefold significant $(\mathrm{p}<0.05)$ increase in serum AST concentration $(226.0+$ $21.36)$ in group 2 when compared with the control $(69.80+1.30)$, more than a twofold significant $(\mathrm{p}<0.05)$ increase in serum ALT concentration $(49.60+11.59)$ in group 2 when compared with control $(20.80+3.11)$, more than fourfold significant $(p<0.05)$ increase in serum ALP concentration $(180.6+18.30)$ in group 2 when compared with control $(41.4+22.11)$, and over threefold significant $(\mathrm{p}<0.05)$ increase in serum GGT concentration $(1.24$ $+0.43)$ in group 2 when compared with control $(0.44+0.11)$. There were however significant $(\mathrm{p}<0.05)$ decreases in all assayed parameters when the ameliorative treatment groups (groups 3 and 4) were compared the cadmium exclusively treated group (group 2) with the exception of ALT levels whose reductions were not significant. Treatment with the extract alone (groups 5 and 6 ) showed non-significant differences in all assayed parameters compared with the control with the exception of ALT concentration at the dose of $200 \mathrm{mg} / \mathrm{kg}$ body weight.
Table 3: Effect of the leafeExtract of Irvingia gabonensis (O'rorke) baill on liver function biomarkers of experimental rats

\begin{tabular}{|c|c|c|c|c|}
\hline Treatment groups & $\operatorname{AST}(\mathrm{U} / \mathrm{dl})$ & $\operatorname{ALT}(\mathrm{U} / \mathrm{dl})$ & $\mathrm{ALP}(\mathrm{U} / \mathrm{dl})$ & $\begin{array}{l}\text { GGT(U/d } \\
\text { l) }\end{array}$ \\
\hline 1.Control & $\begin{array}{l}69.80 \pm 1.30 \\
\text { bcd }\end{array}$ & $\begin{array}{l}20.80 \pm \\
3.11^{\text {bcde }}\end{array}$ & $\begin{array}{l}41.40 \pm \\
22.11^{\mathrm{b}}\end{array}$ & $\begin{array}{l}0.44 \pm \\
0.11^{\mathrm{b}}\end{array}$ \\
\hline $\begin{array}{l}2.10 \mathrm{mg} / \mathrm{kgbw} \\
\mathrm{CdCl}_{2}\end{array}$ & $\begin{array}{l}226.00 \pm \\
21.37^{\text {acd }}\end{array}$ & $\begin{array}{l}49.60 \pm \\
11.59^{\mathrm{a}}\end{array}$ & $\begin{array}{l}180.60 \pm \\
18.30^{\text {acd }}\end{array}$ & $\begin{array}{l}1.24 \pm \\
0.43^{\text {acd }}\end{array}$ \\
\hline $\begin{array}{l}3.10 \mathrm{mg} / \mathrm{kgbw} \\
\mathrm{CdCl}_{2}+200 \mathrm{mg} / \mathrm{kg} \\
\text { bw IG }\end{array}$ & $\begin{array}{l}125.00 \pm \\
64.72^{\mathrm{ab}}\end{array}$ & $\begin{array}{l}44.00 \pm \\
9.67^{\mathrm{a}}\end{array}$ & $\begin{array}{l}59.20 \pm \\
14.10^{\mathrm{b}}\end{array}$ & $\begin{array}{l}0.47 \pm \\
0.14^{\mathrm{b}}\end{array}$ \\
\hline $\begin{array}{l}4.10 \mathrm{mg} / \mathrm{kgbw} \\
\mathrm{CdCl}_{2}+ \\
400 \mathrm{mg} / \mathrm{kgbw} \\
\text { ELEIG }\end{array}$ & $\begin{array}{l}126.60 \pm \\
10.78^{\mathrm{ab}}\end{array}$ & $\begin{array}{l}42.00 \pm \\
11.02^{\mathrm{a}}\end{array}$ & $\begin{array}{l}56.80 \pm \\
9.86^{\mathrm{b}}\end{array}$ & $\begin{array}{l}0.54 \pm \\
0.11^{\mathrm{b}}\end{array}$ \\
\hline $\begin{array}{l}5.200 \mathrm{mg} / \mathrm{kgbw} \\
\text { ELEIG }\end{array}$ & $\begin{array}{l}80.80 \pm \\
9.15\end{array}$ & $\begin{array}{l}42.80 \pm 7.4 \\
6^{\text {af }}\end{array}$ & $\begin{array}{l}48.80 \pm 10 \\
33\end{array}$ & $\begin{array}{l}0.52 \pm \\
0.13\end{array}$ \\
\hline $\begin{array}{l}6.400 \mathrm{mg} / \mathrm{kgbw} \\
\text { ELEIG }\end{array}$ & $\begin{array}{l}86.20 \pm \\
13.52\end{array}$ & $\begin{array}{l}38.60 \pm 3.7 \\
8^{\mathrm{e}}\end{array}$ & $\begin{array}{l}38.60 \pm \\
3.78\end{array}$ & $\begin{array}{l}0.50 \pm 0.0 \\
7\end{array}$ \\
\hline
\end{tabular}

Data expressed as Mean $\pm \mathrm{SD}$

ELEIG= ethanolic leaf extract of Irvingia gabonensis (O'rorke) baill

$\mathrm{a}=$ mean difference statistically significant at $\mathrm{P}<0.05$ when compared with group 1 (control)

$\mathrm{b}=$ mean difference statistically significant at $\mathrm{P}<0.05$ when compared with group 2

$\mathrm{c}=$ mean difference statistically significant at $\mathrm{P}<0.05$ when compared with group 3

$\mathrm{d}=$ mean difference statistically significant at $\mathrm{P}<0.05$ when compared with group 4

$\mathrm{e}=$ mean difference statistically significant at $\mathrm{P}<0.05$ when compared with group 5

$\mathrm{f}=$ mean difference statistically significant at $\mathrm{P}<0.05$ when compared with group 6

\section{Discussion}

Most heavy metals are known environmental pollutants that have been linked with diverse adverse health effects in both humans and experimental animal models (Kaya et al. 2002). Cadmium specifically has been reported to cause kidney and liver impairments. In the present study, the effect of ethanolic leaf extract of Irvingia gabonensis (O'rorke) baill on cadmium-induced nephrotoxicity and hepatotoxicity in wistar albino rats was investigated.

The kidneys and liver are known to be the most prone organs to cadmium exposure / accumulation (Yamano et al. 1999; Yiin et al. 1999, Ryan et al. 2000, Layachi and Kechrid, 2012.). Analyses of kidney function biomarkers like urea, creatinine and electrolytes are very vital in ascertaining the health of the kidneys.

Urea and creatinine are waste products in the blood that are continually filtered out by the kidneys and excreted in the urine. Higher than normal levels of these parameters are therefore an indication of kidney function impairment. In the present study, cadmium accumulation and impairment of kidney function was confirmed with a significant $(\mathrm{p}<0.05)$ increase in the serum concentrations of urea and creatinine in the cadmium exclusively treated groups compared with the normal control. This suggests the inability of the kidney to excrete these compounds indicating impairment in kidney functions such as tubular reabsorption, renal blood flow, and glomerular filtration rate (Bishop et al. 2000). Cadmium has been proposed to exert a direct effect on the glomeruli, leading to the decrease in urea excretion and creatinine clearance (Noonan et al. 2002). This finding is consistent with previous report on the nephrotoxicity of cadmium (Lakshmi et al. 2012, Ojo et al. 2014).Treatment with the plant extract however significantly $(\mathrm{p}<0.05)$ reduced the serum urea and creatinine con- 
centrations in a dose-dependent manner to near-normal when compared with the cadmium exclusively treated group. The effect of the leaf extract may be due to its composition of antioxidant phytochemicals (Gbadegesin et al. 2014, Ewere et al. 2016) combating the oxidative stress induced by cadmium as a proposed mechanism of cadmium nephrotoxicity and hepatotoxicity is generation of reactive oxygen species, (Amoruso and Goldstein, 1982), hydrogen peroxide, (Wong et al. 1990), hydroxyl radicals (Ochi et al. 1998) ultimately altering the antioxidant system in animals as a result of reduced glutathione levels and increased lipid peroxidation which is a primary mechanism for cadmiuminduced toxicity (Zikic et al. 1996, Bagchi et al. 1997, Eneman et al. 2000). The free radicals produced in this process are attached to any available molecule in intracellular environment culminating in cellular damage (Yiin et al. 1999, Murugavel and Pari, 2007). The protective role of Irvingia gabonensis stem bark extract on cadmium-induced nephrotoxicity in rats had also been reported (Ojo et al. 2014). Lakshmi et al. (2012) has also reported the nephroprotective effect of Tribulus terrestris linn in cadmiuminduced nephrotoxicity in rats. Treatments of the experimental rats with the extract alone showed non-significant differences in urea and creatinine concentrations compared with the normal control further indicating its renal protective effect.

An electrolyte is a chemical substance that dissociates into ions when dissolved in water and thus can conduct electricity (Crook, 2006). The principal cations in the body fluids are sodium $\left(\mathrm{Na}^{+}\right)$, potassium $\left(\mathrm{K}^{+}\right)$, calcium $\left(\mathrm{Ca}^{2+}\right)$ and magnesium $\left(\mathrm{Mg}^{2+}\right)$ while chloride $\left(\mathrm{Cl}^{-}\right)$, bicarbonate $\left(\mathrm{HCO}_{3}^{-}\right)$and phosphate $\left(\mathrm{PO}_{4}{ }^{-}\right)$are the most important anions. These electrolytes are distributed both in the extracellular and intracellular fluids at different concentrations and are involved in metabolic activities which are essential to the normal function of all cells (Crook, 2006). The concentrations of the various electrolytes in body fluids are maintained within a narrow range. However, the optimal concentrations differ in the extracellular and intracellular fluid. Certain disease conditions and xenobiotics may lead to electrolyte imbalance (Nwankwo et al. 2006, Crook, 2007). Maintenance of electrolyte balance depends among others on homeostatic mechanisms within the body that regulate the absorption, distribution and excretion of water and its dissolved particles (Burtis et al. 2006). Electrolyte levels are kept constant by the kidneys and hormones. Therefore one of the aims of estimating the serum level of electrolytes is assessing the tubular integrity of nephron (Arvind et al. 2005). In this study, administration of cadmium significantly $(p<0.05)$ raised the serum concentrations of $\mathrm{Na}^{+}, \mathrm{K}^{+}$, and $\mathrm{HCO}_{3}^{-}$compared to the normal control which is an indication of kidney impairment. Treatment with the ethanolic leaf extract of Irvingia gabonensis however ameliorated this effect in a dose dependent manner with the exception of $\mathrm{K}^{+}$ whose reduction was not significant and dose independent. Treatment with the extract alone showed non-significant differences in the serum concentrations of these ions compared with the normal control confirming its renal protective effect.

Serum total protein represents a complex mixture containing a number of components which differ in components and function (Chawla, 2003). Cadmium nephrotoxicity is heralded by increased excretion of $\beta 2$ - microglobulin, retinol binding protein and $\alpha 1$ microglobulin, indicative of decreased proximal tubule function (Gonick, 2008). In the present study however, treatment of the experimental rats with cadmium caused a significant $(\mathrm{p}<0.05)$ increase in serum total protein concentration as compared with the normal control. This may be due to increased synthesis of acute phase proteins by the hepatocytes in trying to combat the depletion of serum proteins arising from the kidney impairment induced by cadmium in the short exposure period. (Cray et al. 2009).

The liver is a major target organ for drug and xenobiotic toxicity because most orally ingested xenobiotics and drugs pass through the liver where some are metabolized into toxic intermediates (Jaeschke et al. 2002). Aspartate aminotransferase (AST) and alanine aminotransferase (ALT) belong to the transaminase family of enzymes. They catalyse the transfer of amino groups between L-alanine and glutamate for biochemical purpose. They are found in large amounts in the liver and also small amounts are found in the heart, kidney and muscles. When the liver suffers from injury or inflammation due to exposure to toxic substances, the level of ALT and AST in the blood is usually elevated. The level of these enzymes in the blood is therefore directly related to the extent of the tissue damage (Lum and Gambino 1972, Halim et al. 1997, Udosen and Ojong, 1998). The results obtained from this study revealed cadmium-induced hepatotoxicity with a significant $(p<0.05)$ increase in the serum concentrations of AST and ALT compared to the normal control. The increase in the serum activities of these enzymes may be attributed to damaged structural integrity of the liver, which culminates in the leakage of these enzymes from the cytosol into the blood stream. This corroborates the findings of Vermaulen et al. (1992) that ALT and AST are normally located in the cytoplasm and released into circulation after cellular damage. This finding is consistent with the report of Layachi and Kechrid, (2012). Treatment with the ethanolic leaf extract significantly $(\mathrm{p}<0.05)$ reduced the serum concentration of AST in a dose-independent manner. The serum concentration of ALT was also reduced with the administration of the extract though this was not significant. This also reflects the hepatoprotective activity of the leaf extract which is probably due to its constituent antioxidant phytochemicals that combats the lipid peroxidation induced by cadmium thereby protecting the liver membrane integrity.

Alkaline phosphatases are enzymes that catalyze the hydrolysis of organic phosphate at alkaline $\mathrm{pH}$. They are found in most tissues but are particularly high in concentration in osteoblasts of bone and the hepatobiliary tract, intestinal wall, kidney tubules and placenta (Crook 2006). Plasma ALP is derived in adults mainly from bone and liver in approximately equal proportions; the proportion due to the bone fraction is increased when there is elevated osteoblastic activity that may be physiological (Crook 2006). Serum ALP activity may also be raised due to primary neoplasm at site other than liver and non-neoplastic hepatobiliary diseases, as in xenobiotic-induced hepatoxicity (Bodansky, 1995).

Gamma-glutamyltransferase (GGT) is the enzyme that catalyzes the extracellular catabolism of glutathione, in the main mammalian cells (Huseby, 1978). It is present on the outer surface of plasma membrane of most cell type and in blood, where it complexes with several plasma components most notably with albumin and lipoprotein (Huseby, 1982). The determination of serum GGT activity is well established diagnostic test for hepatobiliary diseases, and is used as a sensitive marker of liver damage. Elevated serum GGT activity is associated with diseases of the liver, biliary system and pancreas (Betro et al. 1973, Huseby, 1982). In the present study cadmium exclusively treated group showed significantly $(\mathrm{p}<0.05)$ increased serum ALP and GGT activities relative to the normal control. However, treatment with the ethanolic leaf extract significantly $(\mathrm{p}<0.05)$ reduced the activities of the respective enzymes relative to the cadmium exclusively treated group further confirming the hepatoprotective activity of the extract protecting the structural integrity of the liver ultimately preventing / reducing the leakage of these enzymes into the blood stream as these enzymes leak into the blood stream when the structural integrity of the liver is compromised Vermaulen et al. (1992). The hepatoprotective activity of this leaf extract agrees with the previous report by Gbadegesin, et al. (2014) on the hepatoprotective effect of the ethanolic leaf extract of Irvingia gabonensis (O'rorke) baill in sodium arsenite-induced hepatotoxicity in wistar rats.

\section{Conclusion}

From the study conducted, it may therefore be concluded that the ethanolic leaf extract of Irvingia gabonensis (O'Rorke) baill possesses renal and hepatoprotective activity against cadmiuminduced toxicity in wistar albino rats and this may not be unconnected to its constituent antioxidant phytochemicals. 


\section{Acknowledgments}

Special appreciation goes to Mr Akpan of the department of Biochemistry, University of Uyo and the department of Biochemistry, University of Uyo for allowing the use of the animal house and the laboratory. To all the authors whose works were cited, we appreciate you all.

\section{References}

[1] Abd-El-Baset, M., and Abd El-reheem, A. (2008). "The roles of honeybee solution on the physiological parameters of rats exposed to cadmium chloride," Australian Journal of Basic and Applied Sciences. 2: 1438-1453.

[2] Alhazzi, JM. (2008). Cadmium induced Hepatotoxicity and oxidative stress in Rats: Protection by Selenium. Research Journal of En-

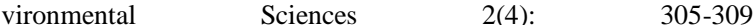
http://dx.doi.org/10.3923/rjes.2008.305.309.

[3] Alvarez, SM., Gómez, NN, Scardapane, L., Fornés, MW, and Giménez, M. S. (2007). "Effects of chronic exposure to cadmium on prostate lipids and morphology," BioMetals, 20(5): 727-741. http://dx.doi.org/10.1007/s10534-006-9036-9.

[4] Ambily, RN., Olivier, D., Karen, S., Emmy, VK. and Ann, C. (2013) Cadmium-Induced Pathologies: Where is the oxidative balance lost (or not)? International Journal of Molecuar Sciences. 14: 6116-6143. http://dx.doi.org/10.3390/ijms14036116.

[5] Amin, A., Hamza, AA. Daoud, S. and Hamza, W. (2006) Spirulina Protects against Cadmium-induced Hepatotoxicity in Rats. American Journal of Pharmacology and Toxicology 1(2): 21-25. http://dx.doi.org/10.3844/ajptsp.2006.21.25.

[6] Amoruso, MA. Witz, G. and Goldstein, BD. (1982) Enhancement of rat and human phagocyte superoxide anion radical production by cadmium in vitro. Toxicology Letters. 10:133-8. http://dx.doi.org/10.1016/0378-4274(82)90064-9.

[7] Arvind, B., Anurag, B., and Shina, M. (2005) Approach to Renal Tubular Disorders. Indian Journal of Pediatrics 72 (9): 771-776. Doi: $10.1007 /$ BF02734150.

[8] Asagba, SO. and Eriyamremu, GE., Adaikpoh, MA. and Ezeoma, A. (2004) Levels of lipid peroxidation, superoxide dismutase, $\mathrm{Na}+\mathrm{K}+-$ ATPase in some tissues of rats exposed to a Nigerian diet and cadmium. Biological Trace Element Research 100(1): 075-086. Doi: 10.1385/BTER.100:1:075

[9] Bagchi, D., Vuchetich, P., Bagchi, M., Hassoun, EA, Tran, MX., Tnag, L. and Stohs, SJ. (1997) Induction of oxidative stress by chronic administration of sodium dichromate [chromium VI] and cadmium chloride [cadmium II] to rats. Free Radical Biology and Medicine 22:471-8. http://dx.doi.org/10.1016/S08915849(96)00352-8

[10] Betro, MG. Oon, RC. and Edwards, JB. (1973) Gamma-glutamyl transpeptidase and other liver function tests in myocardial infarction and heart failure. American Journal of Clinical Pathology 60(5): 679-683. 4148050.http://dx.doi.org/10.1093/ajcp/60.5.679.

[11] Bishop, M., Duben-Engelkirk, J. and Fody, E. (2000) Clinica chemistry: principles, procedures, correlations. 4th ed. Philadelphia (PA): Lippincott Williams and Wilkins.

[12] Bodansky, O. (1995) Enzymes in cancer: The phosphohydrolases. In: Biochemistry of human cancer. Bodansky O. (Ed.), New York: Academic Press. 61-92.

[13] Burtis, CA. Ashwood, ER. And Burns, DE. (2006) Tietz textbook of clinical chemistry and molecular diagnostics (4th ed.). New Delhi: Saunders.

[14] Chawla, R. (2003) Practical Clinical Biochemistry: Methods and interpretations. New Delhi (India): Jaypee Brothers Publishers.

[15] Cray, C., Zaias, J. and Altman, NH. (2009) acute phase response in animals: a review. Comparative Medicine. 6: 517-526.

[16] Crook, MA. (2006) Clinical chemistry and metabolic medicine (7th ed.). New Delhi: Edward Arnold.

[17] Crook, MA. (2007) the kidneys. In: Clinical chemistry and metabolic medicine (8th ed.). M.A. Crook (Ed.), Britian: Brookpower, Pp 36-57.

[18] Cuypers, A., Plusquin, M., Remans, T., Jozefczak, M., Keunen, E., Gielen, H., Opdenakker, K., Nair, A., Munters, E., Artois, T., Nawrot, T., Vangronsveid, J., and Smeets, K. (2010). Cadmium stress: An oxidative challenge. Biometals. 23: 927-940. http://dx.doi.org/10.1007/s10534-010-9329-x.
[19] Eneman, JD, Potts, RJ, Osier, M., Shukla, GS, Lee, CH.Chin, JF and Hart, BA. (2000) Suppressed oxidant induced apoptosis in cadmium adapted alveolar epithelial cells and its potential involvement in cadmium carcinogenesis. Toxicology 7:215-28.

[20] Ewere, EG, Uka, E and Usunobun, U. (2016). Phytochemical Composition, Invitro Antioxidant Activity and Acute Toxicity of Irvingia gabonensis (O’Rorke) Baill Ethanolic Leaf Extract. International Journal of Biological Research. 4 (1): 36-41.

[21] Gbadegesin, MA, Adegoke, AM., Ewere, EG. and Odunola, OA. (2014). Hepatoprotective and anticlastogenic effects of ethanol extract of Irvingia gabonensis (IG) leaves in sodium arsenite-induced toxicity in male Wistar rats. Nigerian Journal of Physiological Sciences. 29: $029-036$.

[22] Gonick, HC. (2008). Nephrotoxicity of cadmium \& lead. Indian Journal of Medical Research. 128: 335-352.

[23] Halim, A., El-Almady, O., Hassab-Allah, S., Abdel-Gelil, F., Hafez, Y. and Derivis, A. (1997) Biochemical effect of antioxidants on lipids and liver function in experimentally induced liver damage. Annals of Clinical Biochemistry. 34:656 663.http://dx.doi.org/10.1177/000456329703400610.

[24] Heinegard. D. and Tiderstrom. G. (1973). Determination of serum creatinine by direct colorimetric method. Clinica Chimica Acta .43(3):305-310. http://dx.doi.org/10.1016/0009-8981(73)90466-X.

[25] Hubert DJ, Wabo FG, Ngameni B, Ngheguin TF, Tchoukoua A, Ambassa P, Abia W, Tchana AN, Giardina S, Buonocore D, Vita FP, Vidari G, Marzatico F, Ngadjui BT. and Moundipa PF. (2010) "In vitrohepatoprotective and antioxidant activities of the crude extract and isolated compounds from Irvingia gabonensis. Asian Journal of Traditional Medicine. 5(3): 79-88.

[26] Huseby, NE. (1978) Multiple forms of gamma-glutamyltransferase in normal human liver, bile and serum. Biochimca et Biophysica Acta 522(2): 354-362. $\quad$ http://dx.doi.org/10.1016/00052744(78)90069-4.

[27] Huseby, NE. (1982) Multiple forms of serum gammaglutamyltransferase. Association of the enzyme with lipoproteins. Clinica Chimica Acta 124(1): 103-112 http://dx.doi.org/10.1016/0009-8981(82)90324-2.

[28] Jaeschke, H., Gores, GJ, Cederbaum, AI, Hinson, JA, Pessayre, D and Lemasters, JJ. (2002) Mechanisms of hepatotoxicity. Toxicological Sciences. 65:166-176. http://dx.doi.org/10.1093/toxsci/65.2.166.

[29] Järup, L., Berglund, M., Elinder, C. G., Nordberg, G. and Vahter, M. (1998). Health effects of cadmium exposure -a review of the literature and a risk estimate. Scandinavian Journal of Work,Environment and Health. 24 (1):1-51. PMID: 9569444

[30] Järup, L., Hellström, L., Alfvén, T., Carlsson, M., Grubb, A., Persson, B., Pettersson, C., Spang, G., Schutz, A., and Elinder, C. (2000). Low level exposure to cadmium and early kidney damage: the OSCAR study. Occupational and Environmental Medicine. 57 (10): 668-672. http://dx.doi.org/10.1136/oem.57.10.668.

[31] Johannes, G., Franziska, S., Christian, G., Vera, E., Paul, B., Andrea, R., and David, A. G. (2006). The toxicity of cadmium and resulting hazards for human health. Journal of Occupational Medicine and Toxicology. 1: 22. http://dx.doi.org/10.1186/1745-6673-1-22.

[32] Kaya, S., Pirincci I., Tras, B., Unsal, A., Bilgili, A, Akar, F., Dogan, A. and Yarsan, E. (2002) Metals, Other Inorganic vet Radioactive Agents. In: Toxicology in Veterinary Medicine, Kaya S I. Pirincci and A. Bilgili (Eds.). 2nd Edn, Medisan Press. Ankara. Pp. 207-250.

[33] Kochmar, JF. and Moss, DW. (1974) Fundamentals of Clinica Chemistry, N.W. Tietz. 604.

[34] Lakshmi, GD., Kumar, PR., Bharavi, K., Annapurna, P., Rajender, B., Patel, PT., Satish Kumar, CSV and Rao, GS. (2012) Protective effect of Tribulus terrestris linn on liver and kidney in cadmium intoxicated rats. Indian Journal of Experimental Biology. 50: 141146.

[35] Layachi, N. and Kechrid, Z. (2012) Combined protective effect of vitamins $\mathrm{C}$ and $\mathrm{E}$ on cadmium induced oxidative liver injury in rats. African Journal of Biotechnology. 11(93): 16013-16020. Doi: 10.5897/AJB12.2665

[36] Liao, XY. Chen, TB, Xie, H. and Liu. YR. (2005). "Soil as contamination and its risk assessment in areas near the industrial districts of Chenzhou City, Southern China," Environment International. 31(6): 791-798. http://dx.doi.org/10.1016/j.envint.2005.05.030.

[37] Limei, Z., Xiaoyong, L., Tongbin, C., Xiulan, Y., Hua, X., Bin, W. and Lixia, W. (2008). "Regional assessment of cadmium pollution in agricultural lands and the potential health risk related to intensive mining activities: a case study in Chenzhou City, China," Journal of Environmental Sciences. $\quad 20 \quad$ (6):696-703. http://dx.doi.org/10.1016/S1001-0742(08)62115-4. 
[38] Liu, J., Qian, SY, Guo, Q., Jiang, J., Waalkes, MP, Mason, RP. and Kadiiska, M. (2008). Cadmium generates reactive oxygen- and carbon-centered radical species in rats: insights from in vivo spintrapping studies. Free Radical Biology and Medicine. 45: 475-481. http://dx.doi.org/10.1016/i.freeradbiomed.2008.04.041.

[39] Lowe AJ, Gillies ACM, Wilson J. and Dawson IK. (2000) Conservation genetics of Bush Mango from Central/West Africa: Implications for RAPD analysis. Molecular Ecology. 9(7): 831 - 841. http://dx.doi.org/10.1046/j.1365-294x.2000.00936.x.

[40] Lum, G, Gambino, SR. (1972) Serum gamma glutamyltranspeptidase activity as an indicator of disease of liver, pancreas, or bone. Clinal Chemistry. 18(4):358-362. PMID: 5012259

[41] Maruna, R. F. (1958). Clinical Chemistry. Acta, 2(1):581.

[42] Matos L, Nzikou JM, Matouba E, Pandzou-Yembe VN Mapepoulou TG, Linder M, Desobry S (2009). Studies of Irvingia gabonensis seeds kernels: Oil technological applications. Pakistan. Journal of Nutrition 8: 151-157. Doi: 10.3923.pjn.2009.151.157.

[43] Murugavel, P., Pari, L. (2007) Effect of diallyl tetrasulfide on cadmium-induced oxidative damage in the liver ofrats. Human and ex$\begin{array}{ll}\text { perimental toxicology 26(6):527-34 } & \end{array}$ http://dx.doi.org/10.1177/0960327107073810.

[44] NAERLS (National Agricultural Extension and Research Liaison Services) (1999) Production and utilization of Ogbono (Irvingia gabonensis). Extension bulletin No 140. Horticulture series No 4 . Pp. 3-12.

[45] Noonan, CW., Sarasua, SM., Campagna, D., Kathman, SJ, Lybarger, JA. and Mueller, PW. (2002) Effects of exposure to low levels of environmental cadmium on renal biomarkers. Environmental Health Perspectives. 110(2): 151-155. http://dx.doi.org/10.1289/ehp.02110151.

[46] Nosiri, C., Abdu-Aguye, I., Hussaini, I. \& Abdurahaman, E. (2009a). Leaf Extracts of Irvingia gabonensis Increase Urine Output and Electrolytes in Rats. The Internet Journal of Alternative Medicine 8(2): http://ispub.com/IJAM/8/2/11789.

[47] Nosiri, C., Hussaini, I., Abdu-Aguye, I. and Abdurahaman, E. (2009b). Pharmacological Effect of Irvingia gabonensis Leaf Extracts on Cat Blood Pressure. The Internet Journal of Pharmacology 9(1): http://ispub.com/IJPHARM/9/1/6633.

[48] Nwankwo, E., Nwankwo, B. and Mubi, B. (2006) Prevalence of impaired kidney in hospitalized hypertensive patients in Maiduguri, Nigeria. Internet Journal of Internal Medicine. 6 (1): 1-10.

[49] Ochi, T., Otsuka, F., Takahashi, K. and Oshawa. M. (1998) Glutathione and metallothioneins as cellular defense against cadmium toxicity in culture Chinese hamster cells. Chemico-biologiy interactions. 65:1-14. http://dx.doi.org/10.1016/0009-2797(88)90026-9.

[50] Ojo, OA, Ajiboye, BO, Oyinloye, BE, Ojo, AB. And Olarewaju, OI. (2014) Protective effect of Irvingia gabonensis stem bark extract on cadmium-induced nephrotoxicity in rats. Interdiscplinary Toxicology. 7: 208-214. http://dx.doi.org/10.2478/intox-2014-0030.

[51] Rajasekaran, A. and Periasamy, M. (2012) Hepatoprotective Effect of Ethanolic Leaf Extract of Calycopteris floribunda Lam on Cadmium-induced Hepatotoxicity in Rats. Research Journal of Pharmaceutical, Biological and Chemical Sciences. 3(3): 382-390.

[52] Thevenod, F. (2009). Cadmium and cellular signaling cascades: To be or not to be? Toxicology and Applied Pharmacology. 238: 221239. Doi: 10.1016.j.taap.2009.01.013.

[53] Thijssen, S., Cuypers, A., Maringwa, J., Smeets, K., Horemans, N., Lambrichts, I., and Van Kerkhove, E. (2007). Low cadmium exposure triggers a biphasic oxidative stress response in mice kidneys. Toxicology. 236(1-2): 29-41. http://dx.doi.org/10.1016/j.tox.2007.03.022.

[54] Tietz, NW. (1976). Fundamentals of clinical chemistry. Philadelphia: W. B. Saunders.

[55] Tobacco, A., Meiatini, F., Moda, E. and Tarli, P. (1979) Simplified enzymatic/colorometric serum urea nitrogen determination. Clinical Chemistry 25(2): 336-337. PMID: 759035

[56] Trinder, P. (1951) A rapid method for the determination of sodium in serum. Analyst. 76:596-599. http://dx.doi.org/10.1039/an9517600596.

[57] Udeala O, Onyechi J. and Agu S. (1980) Sourcing Pharmaceutical Raw Materials from Indigenous Medicinal plants. Journal of Pharmacy and Pharmacology. 32:36.

[58] Udosen, EO, Ojong, AS. (1998) hepatotoxic activity of Sacoglothis gabonensis in rats. Pharmaceutical Biology. 36(5):467-469. http://dx.doi.org/10.1076/phbi.36.5.368.4648

[59] Vermuelen, NPE, Bessems, JGM, Van de straat, R. (1992) Molecular aspects of paraceutamol-induced hepatotoxity and its mechanism-based prevention. Drug Metabolism Reviews. 24(3): 367-407. http://dx.doi.org/10.3109/03602539208996298.
[60] Wong, Z., Troll, W., Koenig, KL., Frenkel, K. (1990) Carcinogenic sulfide salts of nickel and cadmium-induced $\mathrm{H}_{2} \mathrm{O}_{2}$ formation by human polymorphonuclear leukocytes. Cancer Research. 20:756470.

[61] Yamano, T., Kosanke, SD, and Rikans, LE. (1999) Attenuation of cadmium-induced liver injury in senescent male Fischer 344 rats: role of metallothionein and glutathione. Toxicology and Applied Pharmacology. 161(3): 225-230. http://dx.doi.org/10.1006/taap.1999.8813.

[62] Yiin, SJ, Chern, CL., Sheu, JY., Tseng, WC., and Lin, TH. (1999) Cadmium-induced renal lipid peroxidation in rats and protection by selenium. Journal of Toxicology and Environmental Health. 57(6) 403-413. http://dx.doi.org/10.1080/009841099157601.

[63] Young, DS., Davis, RB., O'Connor, BB. and Eisenberg, DM. (1975) Clinical Chemistry. 21:5

[64] Young, DS. (1990) Effects of Drugs on clinical Laboratory Tests, 3rd edn., AACC Press. Washington D.C.

[65] Zikic, RV., Stajn, A., Saicic, ZS., Spasic, MB., Ziemnicki, K. and Petrovic, VM. (1996) The activities of superoxide dismutase, catalase and ascorbic acid content in the liver of goldfish (Carassius auratus gibelio Bloch.) exposed to cadmium. Physiology Research 4596):479-481. PMID: 9085381. 